\title{
Deficiency of regulatory $B$ cells in a house dust mite model of asthma
}

\author{
Faouzi Braza ${ }^{1,2,3^{*}}$, Julie Chesné ${ }^{1,3}$, G Mahay $^{3}$, MA Cheminant ${ }^{3}$, D Lair $^{3}$, K Botturi-Cavaillès $^{1}$, Antoine Magnan ${ }^{3}$, \\ Sophie Brouard ${ }^{2}$
}

From 7th European Workshop on Immune-Mediated Inflammatory Diseases

Noordwijk aan Zee, the Netherlands. 28-30 November 2012

\section{Introduction}

Asthma is a chronic disorder leading to bronchial obstruction in response to inhaled allergen. It is associated with immune deregulation with specific expansion of $\mathrm{Th}_{2}$ and $\mathrm{Th}_{17} \mathrm{CD}^{+} \mathrm{T}$ cells. Both $\mathrm{T}$ cell populations support B cells response by stimulating their proliferation, survival and IgE secretion. B cells are described for their effector functions but recently reports have described their regulatory role in autoimmune and inflammatory disorders. However, definitive identification has been challenging because regulatory B cells (Breg) are rare, do not have a specific marker, and express detectable IL-10 or TGF- $\beta$ only upon ex vivo stimulation. In OVA asthma models, local inhalation tolerance [1], [2] and infections with helminthes [3], [4] induce the generation of regulatory B cells. But no physiological role of this population in the development of asthma has been described yet.

\section{Methods}

Mice were sensitized on days $0,7,14$ and 21 by percutaneous administration of HDM onto the ears. Intra-nasal challenges were performed on day 27 and 34 with $250 \mu \mathrm{g}$ HDM. One day after each challenge, we realized by flow cytometry a complete B cell phenotyping in spleen and lungs.

Splenocytes and lung cells were isolated and stimulated ex vivo with LPS and PMA, ionomycin to induce IL-10 secretion by B cells.

\section{Results}

No differential frequency was observed for all B cell populations in the spleen of HDM allergic mice, suggesting a normal B cell development. In contrast, HDM allergic

Tuniversité de Nantes, France

Full list of author information is available at the end of the article mice exhibit a strong infiltration of $\mathrm{CD} 19^{+} \mathrm{B}$ cells in lungs and broncho-alveolar lavage after the second challenge. We found an increase of CD19 $\operatorname{IgD}^{\text {hi }} \operatorname{IgM}^{\text {low }}$ B2 mature and CD19 IgD- IgM- switched memory B cells in the lung of HDM allergic compared to control mice. We looked at $\mathrm{CD} 19^{+} \mathrm{IL}^{-10^{+}} \mathrm{CD}_{1 \mathrm{~d}^{\mathrm{hi}}} \mathrm{CD}^{+} \mathrm{CD} 21^{+} \mathrm{CD} 24^{\mathrm{hi}} \mathrm{IgM}^{\mathrm{hi}}$ B cell population that has been shown to display regulatory properties in other situations. Whereas this population is present in spleen and lungs of HDM allergic mice, it produces less IL-10 than control after the first and the second challenge both in lung (vs control, $\mathrm{p}<0.01$ ) and spleen (vs control, $\mathrm{p}<0.05)$.

\section{Conclusions}

Our results strongly suggest a potential defect of regulatory B cells in the course of asthma. Future investigations will focus on their capacities to inhibit bronchial hyperreactivity and inflammatory responses.

\section{Author details}

'Université de Nantes, France. ${ }^{2}$ UMR_S1084, Institut de transplantation d'urologie et néphrologie, Nantes, France. ${ }^{3}$ UMR_S 1087, Institut du Thorax, Nantes, France.

\section{Published: 28 November 2012}

\section{References}

1. Singh A, Carson WF, Secor ER, Guernsey LA, Flavell RA, Clark RB, Thrall RS, Schramm CM: Regulatory role of $B$ cells in a murine model of allergic airway disease. J. Immunol 2008, 180(no. 11):7318-7326.

2. Natarajan P, Singh A, McNamara JT, Secor ER, Guernsey LA, Thrall RS, Schramm CM: Regulatory B cells from hilar lymph nodes of tolerant mice in a murine model of allergic airway disease are CD5(+), express TGF- $\beta$, and co-localize with CD4(+)Foxp3(+) T cells. T cells 2012, 1-11.

3. A S, S SP, K M, M NE, A A, F PG: Regulatory $B$ cells prevent and reverse allergic airway inflammation via FoxP3-positive T regulatory cells in a murine model. Journal of Allergy and Clinical Immunology 2010, 125(no. 5):1114-1124.e8.

4. van der Vlugt LEPM, Labuda LA, Ozir-Fazalalikhan A, Lievers E, Gloudemans AK, Liu K-Y, Barr TA, Sparwasser T, Boon L, Ngoa UA,

\section{()


Feugap EN, Adegnika AA, Kremsner PG, Gray D, Yazdanbakhsh M, Smits HH: Schistosomes induce regulatory features in human and mouse $\mathrm{CD} 1 \mathrm{~d}(\mathrm{hi})$ $B$ cells: inhibition of allergic inflammation by IL-10 and regulatory T cells. PLOS ONE 2012, no. 7(2):e30883.

doi:10.1186/1479-5876-10-S3-P25

Cite this article as: Braza et al:: Deficiency of regulatory B cells in a

house dust mite model of asthma. Journal of Translational Medicine 2012

10(Suppl 3):P25.

Submit your next manuscript to BioMed Central and take full advantage of:

- Convenient online submission

- Thorough peer review

- No space constraints or color figure charges

- Immediate publication on acceptance

- Inclusion in PubMed, CAS, Scopus and Google Scholar

- Research which is freely available for redistribution

Submit your manuscript at www.biomedcentral.com/submit 